\title{
Construction of a Parentification Questionnaire for Youth
}

\begin{abstract}
BACKGROUND
Parentification is defined as a pattern of family interactions in which a child or an adolescent provides excessive care to the parents instead of receiving it from them. The phenomenon is linked to family difficulties, personality disorders or abuse of psychoactive substances, yet in some circumstances, it may be a factor contributing to an increase in mental resilience and one's independence.
\end{abstract}

\section{PARTICIPANTS AND PROCEDURE}

The aim of the study was to prepare a parentification questionnaire for adolescents, adapted to Polish cultural conditions. The study involved 641 teenagers.

\section{RESULTS}

On the basis of confirmatory factor analysis, two versions of the tool were created: for adolescents without siblings ( 4 basic subscales) and for adolescents with siblings ( 4 basic and 2 additional subscales).

\section{CONCLUSIONS}

The questionnaire draws attention to the multidimensional character of the phenomenon of parentification, focusing on the type of roles and tasks performed by a teenager (i.e. emotional and instrumental parentification), the level of a sense of injustice and satisfaction with the role played in the family system. Additionally, the test allows us to focus on the recipient of the care provided by the child (parents or siblings) while maintaining a structure that allows for conducting research with both only children and persons with siblings and facilitates comparison between them.

\section{KEY WORDS}

family role reversal; measurement; adolescents; only children; siblings

ORGANIZATION - Institute of Psychology, University of Gdansk, Gdansk, Poland

aUthors' contributions - A: Study design - B: Data collection - C: Statistical analysis - D: Data interpretation .

E: Manuscript preparation - F: Literature search · G: Funds collection

CORRESPONDING AUTHOR - Judyta Borchet, Institute of Psychology, University of Gdansk, 4 Bażyńskiego Str.,

80-309 Gdansk, Poland, e-mail: judyta.borchet@ug.edu.pl

to Cite this ARTicle - Borchet, J., Lewandowska-Walter, A., Połomski, P., \& Peplińska, A. (2020). Construction

of a Parentification Questionnaire for Youth. Health Psychology Report, 8(2), 175-188. https://doi.org/10.5114/

hpr.2019.89492

RECEIVED 12.07.2019 • REVIEWED 17.09.2019 • ACCEPTED 18.09.2019 • PUBLISHED 30.10.2019 


\section{BACKGROUND}

The term "parentification" was coined by the authors of the family systems theory. Minuchin et al. (1967) drew attention to the weakness of a family in which the parental competence of the adult is insufficient and, as a result, the child is delegated to fulfil their roles. Boszormenyi-Nagy and Spark (1973) pointed to the neglect of the needs of the child in a family in which he or she performs the duties of others, which may favour intergenerational transmission of the role reversal mechanism. The way of fulfilling roles in the family is repeated in the next generation - a parent who was parentified in their childhood expects instrumental and emotional support from his or her children. Parentification is a violation of internal family boundaries and means that the child is bound by others or feels bound to take emotional, instrumental and sometimes financial responsibility for other family members (Boszormenyi-Nagy \& Spark, 1973; Jurkovic, 1997; Hooper, Marotta, \& Lanthier, 2008; Hooper, DeCoster, White, \& Voltz, 2011a; Hooper, Doehler, Wallace, \& Hannah, 2011b; Hooper, 2012; Schier, 2010, 2014). A situation is created in the family in which the balance of the system is maintained by reversing the parent-child hierarchy. A system in which the parent is unavailable to the child and the child is to be available to the parent and siblings becomes a source of stress for the child (Bowen, 1978) and interferes with the accomplishment of age-appropriate developmental goals. Parentified children incur double losses because not only do they lose an opportunity to develop their relationship with parents and siblings properly, but also they experience difficulties in carrying out non-family tasks such as school education and developing relationships with their peers. Parentification as a permanent pattern of family functioning is a form of child neglect. In contrast to more open forms of child abuse, however, it can be more difficult to identify, partly because of the desire of the family members to protect the image of the family (see: Tedgård, Råstam, \& Wirtberg, 2019). Therefore, it is necessary to create tools allowing for a multidimensional diagnosis of the phenomenon, including from the perspective of the child.

Parentification is a common phenomenon experienced by children worldwide (Boszormenyi-Nagy \& Spark, 1973; Bying-Hall, 2008; Hooper, 2007; Żarczyńska-Hyla, Zdaniuk, Piechnik-Borusowska, KarczTaranowicz, \& Kromolicka, 2016). The development of works dedicated to the construct of "parentification" in the empirical dimension and an assessment of the phenomenon in many countries was made possible by the emergence of tools created by Jurkovic and his collaborators $(1998,2001)$ and by the Hooper questionnaire (2009). In Poland, due to the lack of available tools to diagnose parentification in the population, the prevalence of the phenomenon can only be estimated indirectly, on the basis of statistics on the number of children growing up in dysfunctional families and/or placed in care due to insufficient care and educational competences of their parents. Polish families are undergoing huge transformations (Slany, 2002; Szredzinska, 2017; Kolankiewicz, 2017), while at least some of the forms of the transformation are conducive to the emergence of parentification, i.e. to imposing the burden of the tasks and roles of adult family members, who are physically or emotionally absent, on the child. They include, among others: 1) increase in the number of divorces, 2) increase in the number of single-parent families, 3) economic migration of parents (East, 2010; Schier, 2014).

Divorce is a worrying social phenomenon. In 2008, the total number of divorces in families with children amounted to 43,173 (Cudak, 2011), and in 2015 over 67,000 spouses separated while bringing up 39,100 minor children, more than half of whom were 7-15 years old at the time of the divorce (Szredzińska, 2017). In recent years, the number of divorces has stabilised in Poland, which, compared to other European countries, maintains one of the lowest levels of marriage breakdowns. In sociological terms, divorce is an indicator of family breakdown, and in psychological terms, it is a threat to the functioning of the family and the stability of its structure (Cudak, 2011). In Poland, the number of single parents is increasing (in 2011, one in five children were being brought up in such families). However, it is worth noting that the number of families in which fathers are single parents is growing dynamically (cf. Szredzińska, 2017). Today’s single parents are often well-off individuals who, as one may assume, often consciously choose lone parenthood. However, the second group of single parents is still made up of people in difficult economic and living conditions, such as unmarried women abandoned by the fathers of their children (Sikorska, 2009).

After Poland's accession to the European Union, the number of labour migrations increased, including in the case of individuals bringing up children. More families chose the option of one parent leaving their children in Poland under the care of the other parent. Research conducted in 2014 on behalf of the Polish Children's Rights Ombudsman shows that about $20 \%$ of children aged 10-19 experienced temporary separation from at least one parent, with the father ( $68 \%$ of children) leaving more often than the mother ( $14.8 \%$ of children). Periodic absence of both parents due to economic migration was experienced by $17.2 \%$ of children from this group. The purpose of the parents' travel was of course to improve the living conditions of their families, but it had a negative impact on the sense of security of their children, weakening the bonds between the spouses and the relationship between the absent parent and the child. In families separated due to migration, educational problems were also more common (Tarka, 2014). 
In addition to these three risk factors of parentification, there is a high - and still growing - number of children and young people whose parents experience such serious difficulties with their upbringing that a family court needs to interfere in the manner they exercise parental authority. The number of children under judicial supervision has been growing for years (Kolankiewicz, 2017). The main reasons for court interference in the exercise of parental authority and for placing children in foster families and care and educational institutions, with significant negligence on the part of the parents, are alcoholism of the parents (or one of them), physical and psychological abuse towards family members, somatic or mental illnesses of the parent, helplessness with regard to care and educational matters and other everyday matters, parents leaving the country, and death of both parents or one of them (Szymańczak, 2016). These factors have been identified as a threat to parentification by many researchers (Hooper et al., 2011b; Macfie, Brumariu, \& Lyons-Ruth, 2015; Nuttall \& Valentino, 2017; Schier, 2014; Grzegorzewska, 2016).

An analysis of available parentification measurement tools shows that their authors focus on different dimensions of the phenomenon, which is reflected in the construction of the questionnaires. The most widely known dimensions of parentification are divided by its type (i.e. instrumental and emotional parentification) and possible consequences (Jurkovic, 1997). The author distinguishes two types of parentification - the emotional and instrumental one. The emotional type of parentification refers to the child satisfying the emotional and social needs of other family members as well as attempting to maintain a positive family atmosphere. Caregiving for the emotional needs of parents or siblings may be evidenced through attention to their well-being and sensitivity to the other family members' moods (Jurkovic, 1997; Hooper et al., 2008; Hooper \& Wallace, 2010; Hooper et al., 2011b). In order to maintain positive feelings within the family, a child experiencing emotional parentification may be cast in various roles, for example, as a mediator for conflicted household members, a caregiver looking after a sick family member, scapegoat, parental therapist, confidant or a partner substitute (i.e., spousification; see Kerig \& Brown, 1996; Sroufe \& Ward, 1980) in a situation where parents have separated (Hooper et al., 2008; Hooper \& Wallace, 2010; Hooper et al., 2011b). The main concern in the case of instrumental parentification is to care for the family's material well-being (Jurkovic, 1997; Hooper et al., 2008; Hooper \& Wallace, 2010; Hooper et al., 2011b). In such situations children offer assistance to the family by organizing their everyday life and do so through their own physical work (e.g., cleaning, cooking, doing the laundry, shopping, looking after their siblings, or earning money). Some researchers believe that instrumental parentification is less deleterious than emotional parentification (Jurkovic, 1997; Hooper et al., 2008). Byng-Hall (2008) points out that children find it easier to adapt to instrumental roles and responsibilities than emotional roles, as the latter exposes them to a higher degree of stress-related psychological costs. The stress follows from a sense of responsibility for another person. However, it must be noted that the dimensions of parentification distinguished by Jurkovic (1997) are not mutually exclusive. Children may serve in a variety of roles within the family, with both types of parentification (i.e., emotional and instrumental) occurring simultaneously (cf. Jurkovic, 1997; Kerig, 2005).

The second classification of parentification proposed by Jurkovic (1997) also concentrates on the positive and negative consequences of parentification as experienced by the child. Jurkovic (1997) differentiates between constructive (adaptive) and destructive (pathological) parentification. Parentification may be understood as a form of emotional violence if it overburdens the child with roles normally reserved for adults, and in so doing, prevents children from pursuing their own developmental tasks (Jurkovic, 1997) or enjoying childhood (Schier, 2010). A situation that is beyond children's or adolescents' scope, draining their mental resources, usually brings negative - and sometimes traumatic - consequences. A survey of the body of research on parentification showed a link between parentification and anxiety disorders, personality disorders, and eating disorders (Hooper et al., 2011a). In addition, the literature suggests that parentification is related to abusing psychoactive substances (Chase, Deming, \& Wells, 1998), mental disorders (Jones \& Wells, 1996), relationship dysfunctions (Shaffer \& Madden, 2016) as well as poor parenting skills in adulthood (BoszormenyiNagy \& Spark, 1973; Bowen, 1978; Chase et al., 1998; Nuttall, Zhang, Valentino, \& Borkowski, 2019). Children who experience parentification are raised under unfavourable conditions affecting their ability to form positive relationships as well as impacting their mental growth. An impoverished environment may become a source of trauma (cf. Cichetti, 2004; Schier, 2014). At the same time, a moderate intensification of parentification, as a normative response to a temporary family crisis, may bring positive long-term results for the child, such as an increase in self-esteem, empathy or altruism (Jurkovic, 1997; McMahon \& Luthar, 2007). The child's assumption of the roles of an adult family member may have a positive impact on the child's development if the following conditions are met: 1 ) the hierarchy reversal is temporary and is not a permanent family functioning pattern, 2) the child is clearly informed about the duties to be undertaken and feels that the other family members are grateful for the work they undertake. Therefore, it is important when diagnosing parentification to include not only objective indicators of (what the child does in the family), but also a subjective assessment
Parentification Questionnaire for Youth 
Judyta Borchet, Aleksandra LewandowskaWalter, Piotr Połomski, Aleksandra Peplińska of, the burden resulting from taking over the parent's tasks (the way the child perceives his/her role - as a factor threatening the fulfilment of other life roles and an expression of injustice on the part of the parent or as a situation allowing the child to acquire new skills and to develop positive personality traits). In the available tools, the authors describe that dimension of parentification as "perceived unfairness" (Jurkovic \& Thirkield, 1999; Jurkovic, Kuperminc, Sarac, \& Weisshaar, 2005) and "perceived benefits of parentification” (Hooper, 2009). Consideration of this dimension of parentification may be important in Poland due to the specific cultural conditions linked to the high distance of authority (Hofstede, 2011). With a strong parent-child hierarchy in vertical relations, the child accepts the assigned tasks as normative, even if they are burdensome and prevent the child from carrying out developmental tasks. By protecting the image of the family and by protecting themselves from discomfort, children can make positive changes to their lives and seek to benefit from tasks which they have been assigned at home.

The last classification, taken into account by Hooper (2009), distinguishes parent-focused parentification and sibling-focused parentification. In families where there is a disturbed hierarchy and border blurring, and consequently a reversal of roles, the child takes on the duties of an adult carer and performs them 1) directly towards the parent, in an instrumental form if the parent is ill or disabled or by emotionally supporting them in case of a crisis such as divorce, 2) or indirectly, caring for his or her siblings and performing practical tasks or caring for the wellbeing of their brothers and sisters. The author thus emphasizes the multitude of roles that a child can play in relation to various family members and their influence on the functioning of the whole family system, individual subsystems (e.g. siblings) and the parent-child dyad. The situation of an only child in the family is special when considering the phenomenon of parentification. Such children usually receive huge amounts of everything the parents have to offer: love and care, but also criticism, anger, fear, and anxiety. An only child has to confront the feelings of adults on his/her own and in many cases it can be a burden for him/her. If the parents are emotionally mature, it is a very advantageous situation for the child - he or she has a sense of support, acceptance and feels safe in the family; but if the parents are prone to conflict or incompetent, the fact that the child is the only recipient of their reaction can be very traumatic for him/her (Richardson \& Richardson, 1999). An only child does not have a brother or a sister to confide in and is therefore much more burdened with a family crisis situation, which results in a higher level of aggressiveness and depression in only children than in children with siblings and in an increase in school difficulties (Roberts \& Blanton, 2001; Sorensen, 2008).

\section{AIM OF THE STUDY}

The aim of the research was to prepare the first tool in Poland for measuring parentification intended for adolescents. The authors of the questionnaire were inspired by two American questionnaires: the Filial Responsibility Scale (FRS; Jurkovic \& Thirkield, 1999; Jurkovic et al., 2005) and the Parentification Inventory (PI; Hooper, 2009). The first one consists of three subscales which are: perceived fairness, emotional caregiving and instrumental caregiving (Jurkovic \& Thirkield, 1999; Jurkovic et al., 2005). The Parentification Inventory by Hooper (2009) distinguishes parentification directed to the parent, parentification focused on siblings and perceived benefits of parentification. Combining those two approaches while creating the Parentification Questionnaire for Youth (Kwestionariusz Parentyfikacji dla Młodzieży; $\mathrm{KPdM}$ ) enabled us to examine not only the type of the child's caregiving (emotional and instrumental) and the care's recipients (parents and siblings) but also one's perception of his/her situation (satisfaction with the family role and the sense of injustice). Additionally, two versions of the tool were proposed - for only children and for children with siblings.

Due to the persistent strong attachment to the cultural norm, which is a reluctance in Poland to reveal family problems outside the family and a difficulty for children to report aggravating family situations (see: Schier, 2019), it was important to create a multidimensional tool which, taking into account different perspectives and different dimensions of the structure, would be helpful in assessing the intensity of the problem of parentification.

\section{PARTICIPANTS AND PROCEDURE}

\section{PARTICIPANTS}

The survey involved 641 teenagers living in Pomerania, $38.8 \%$ of whom were boys. $0.5 \%$ of the respondents did not specify their gender. The teenagers were aged between 12 and $18(M=14.96, S D=0.36)$. Only children accounted for about $25 \%$ of the sample. Adolescents with siblings had between 1 and 8 brothers and/or sisters $(M=1.70, S D=1.15)$. The teenagers came from families with different family structures. $82.1 \%$ of the teenagers came from two-parent families, $10 \%$ lived with a single parent and $7.3 \%$ were being brought up in reconstructed families. Data on the family structure were not provided by $0.6 \%$ of the surveyed teenagers. The participants were students of 3 different schools who accepted the invitation to participate in the study $\left(n_{1}=189, n_{2}=49, n_{3}=403\right)$. Two of the schools were located in two different and distant parts of the city of Gdańsk ( $n_{2}-$ Dolne Miasto, $n_{3}-$ Osowa), while one was located in Sztutowo 
village $\left(n_{1}\right)$. Four other schools from Gdansk and one school from Masuria voivodeship rejected the invitation to participate in the study.

\section{PROCEDURE}

Prior to the study, a positive opinion of the Ethics Committee for Research Projects at the Institute of Psychology of the University of Gdansk was obtained. The research was carried out at the schools attended by the examined children at the beginning of the school years 2016/2017 and 2017/2018. The survey was preceded by obtaining consent from the school management to hold the survey on the school grounds and consent from parents for their children to participate in the survey. The study was a group study and took place in school classrooms. Questionnaires were filled in by one class simultaneously (from 20 to 30 people). Initially, the pupils were given basic information on how to complete the forms and were assured of the voluntary and anonymous nature of their participation in the survey. Each student completed the questionnaires on their own. The whole procedure took about 20-25 minutes. Finally, the young people were thanked for their participation in the survey.

\section{MEASURES}

Participants were asked to complete a short set of measures: a researcher-designed questionnaire related to demographic data (such as sex, age, family type, mean grade from last year, number of siblings, birth order), family socioeconomic status measurement, parental conflict measurement, and the KPdM experimental version.

Parentification Questionnaire for Youth (KPdM) in the experimental version consisted of 66 theorydriven items. Sample items were: "Sometimes I think I am more responsible than my parents", "Most children my age have the same roles and responsibilities as me" and "I defend my siblings and excuse their actions to my parents". The source of the contents of the statements was an analysis of literature on parentification and items from the tools which served as inspiration for the authors (cf. Jurkovic, 1997; Jurkovic \& Thirkield, 1999; Hooper, 2009). All the statements were rated on a 5-point Likert scale and were preceded with the following instruction: Below, there are statements about your thoughts, behaviours, and feelings about you and your family. Please read each of them carefully. Choose an answer based on how true the sentence is on a scale of 1 (never is) and 5 (always is). There are no right or wrong answers here. Make sure you answer each question as accurately as possible.

Parental conflict was assessed subjectively. The participants were asked to grade the level of conflict be- tween their parents on a Likert-type scale. Participants responded using a scale of 1 to 5 , where 1 represents no conflict or tension between parents and 5 represents very strong conflict and tension between parents.

Socio-economic status of the family (SES) assessed with an image of a 10-point ladder. The first one is the teen's subjective assessment of the family's economic situation inspired by MacArthur's Scale of Subjective Social Status (Goodman et al., 2001). Recipients are presented with an image of a ladder and follow the instruction: Imagine that the ladder you see represents different people in society. At the top there are the richest people (10) and at the bottom of the ladder there are the poorest people (1). Indicate where on this ladder you would put your family (Goodman et al., 2001). The teens participating in this study rated their families as being slightly above average $(M=6.48, S D=1.46)$. $23.6 \%$ of participants ranked their family 5 or lower.

\section{RESULTS}

\section{CONFIRMATORY FACTOR ANALYSIS}

In order to verify the consistency of distribution of test items of the tool with theoretical assumptions, confirmatory factor analysis was carried out on the basis of the collected results based on structural equation modelling using AMOS 24 software. In the following models concerning the two versions of the tool, i.e. for young people with siblings and for only children (Figures 1 and 2), it was assumed that there were four basic latent variables (both versions) which determined the structure of the questionnaire items, i.e. "Emotional parentification towards parent", "Instrumental parentification towards parent" and "Satisfaction with the role" (seen as the benefits of parentification) and a "Sense of injustice" (cf. Jurkovic, 1997; Jurkovic \& Thirkield, 1999; Hooper, 2009). The version of the tool which does not include only children in the study also has variables related to relations with siblings in the scope of the studied phenomenon, i.e. "Emotional parentification towards siblings" and "Instrumental parentification towards siblings" (cf. Hooper, 2009).

The assumed system of variables in the presented structural models was tested in terms of data matching quality parameters. It was found (Tables 1 and 2) that these data were satisfactory and showed an acceptable fit (Konarski, 2010) of the models to the data (the items qualified for the final version of the tool were those whose value of factor loadings was above 0.3 ). The final resultant path diagram for the two versions of the tool is presented in Figures 3 and 4.

At the next stage, the model quality analysis was carried out by examining the values of factor loads (standardized values of pathway coefficients for test items and latent variables) and the percentage of explained variance (multiple correlation coefficient). In
Parentification Questionnaire for Youth 
Judyta Borchet,

Aleksandra

Lewandowska-

Walter,

Piotr Połomski,

Aleksandra

Peplińska

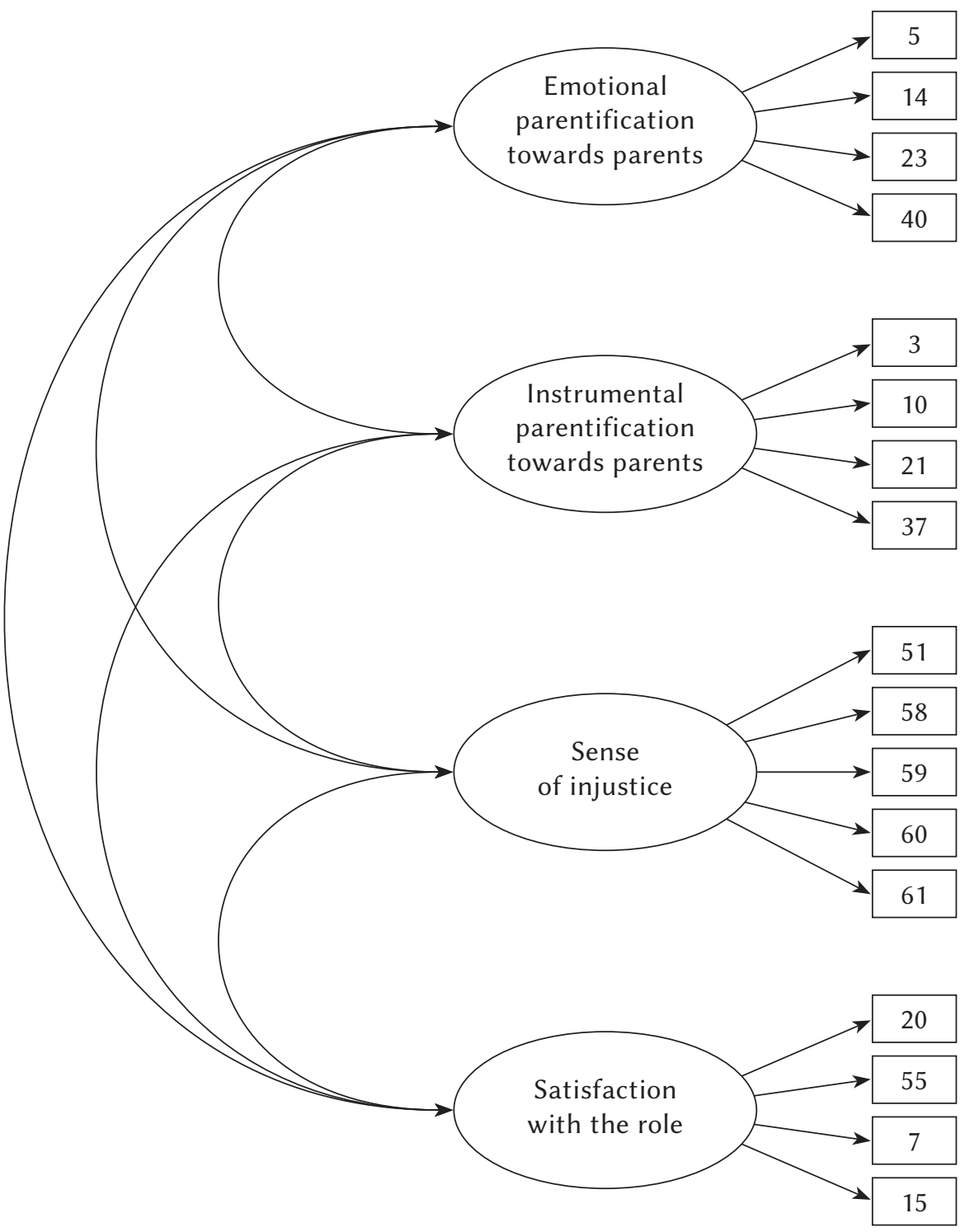

Figure 1. Path diagram of latent variables and test items for KPdM confirmatory factorial analysis model for adolescents without siblings based on theoretical assumptions.

the case of almost all test positions of each tool version (Tables 3 and 4) the values of factor loads exceeded 0.4, which is an average result (Konarski, 2010) and some of them 0.7 and 0.8 , which constitutes a good and very good result. In the version of the tool for only children, questions 5, 21 and 55 (in the version for young people with siblings, also questions 21, 55 and 13) appear to be the weakest in this respect, but their loads are greater than 0.3 and, above all, statistically significant, which is an acceptable result (Bedyńska \& Książek, 2012).

In general, the models in both tool versions are acceptable - the model fit parameters, as well as most of the load indicators for the tool items, reach the desired values.

The main version of the tool, which is intended for only children as well as children who have siblings, consists of 17 items based on 4 factors. The first fac- tor, "Emotional parentification towards parents" includes 4 items referring to taking care of the parent's emotional condition, e.g. helping solve the parental conflicts, assisting them when making decisions or solacing them (sample item: "I comfort my parents when they are sad"). The second factor, "Instrumental parentification towards parents" comprises 4 test items describing financial aid and housework that the child may do to support parents, which for example are giving money to the parents or doing the shopping for the family (e.g. "When I earn or get money, I give it to my parents"). "Sense of injustice", the third factor, includes 5 statements that refer to the feeling of being used, unseen and unappreciated by the family members (for instance: "I sacrifice myself in my family, but it goes unnoticed by other family members"). The fourth subscale, "Satisfaction with the family role" 


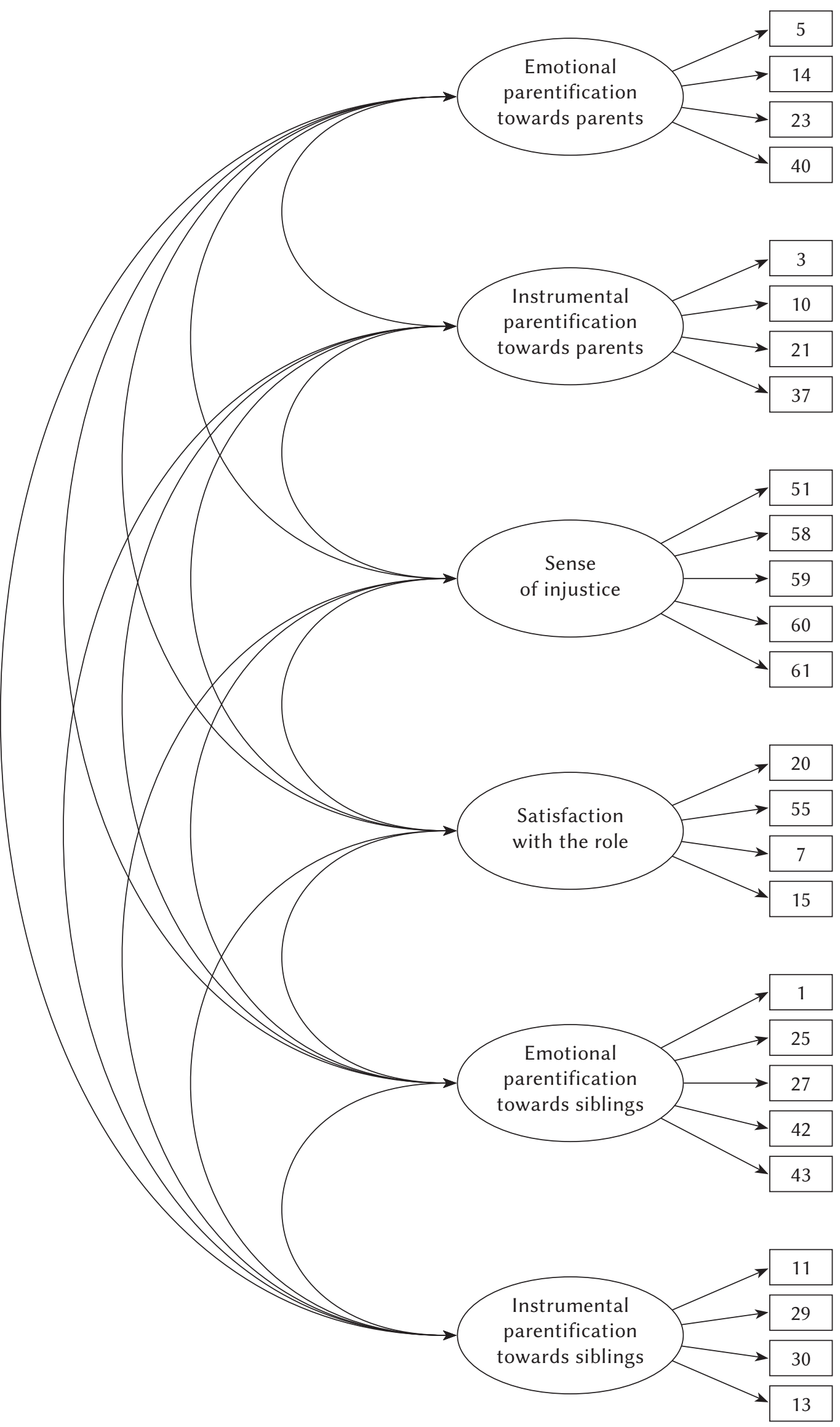

Figure 2. Path diagram of latent variables and test items for KPdM confirmatory factor analysis model for adolescents with siblings based on theoretical assumptions. 
is composed of 4 items referring to assessment of one's role in the family. The items refer to feeling appreciated, perceived cooperation in the family as well as openness in talking about the child's role (e.g. "I am very happy with the role I play in my family").

The two additional scales ("Emotional parentification towards siblings" and "Instrumental parentification towards siblings") are designed for individuals with siblings. The "Emotional parentification towards

Judyta Borchet,

Aleksandra

Lewandowska-

Walter,

Piotr Połomski,

Aleksandra

Peplińska
Table 1

Global model-to-data fit ratio for the only-child version

\begin{tabular}{lrrr}
\hline$\chi^{2}(113)=162.18$, & RMSEA $=$ & GFI $=$ & CFI $=$ \\
$p=.002$ & 0.061 & 0.841 & 0.886 \\
\hline
\end{tabular}

siblings" subscale consists of 5 items that cover comforting siblings, worrying about them and protecting them from the parents (e.g. "I defend my siblings and explain them to my parents"). The last factor, "Instrumental parentification towards siblings" includes 4 items referring to relieving the siblings from the housework, helping them with the school, as well as disciplining them (sample item: "I help my siblings in household chores, e.g. cleaning, walking the dog”).

Table 2

Global model-to-data fit ratio for the child with siblings version

\begin{tabular}{lccc}
\hline$\chi^{2}(284)=693.82$, & RMSEA $=$ & GFI $=$ & CFI $=$ \\
$p<.001$ & 0.054 & 0.901 & 0.901 \\
\hline
\end{tabular}

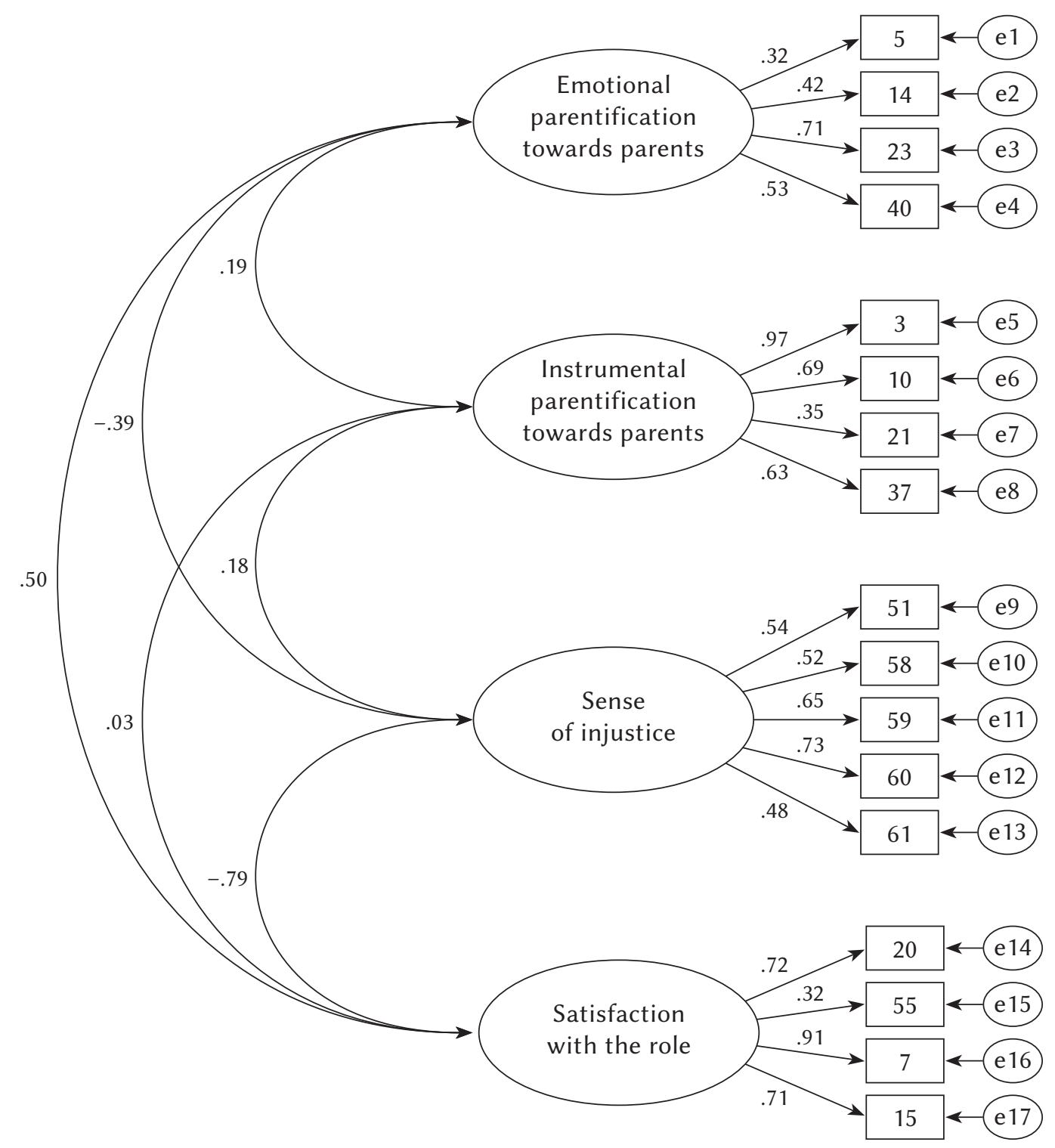

Figure 3. Resultant path diagram of latent variables and test items for the model of KPdM confirmatory factor analysis for only children. 


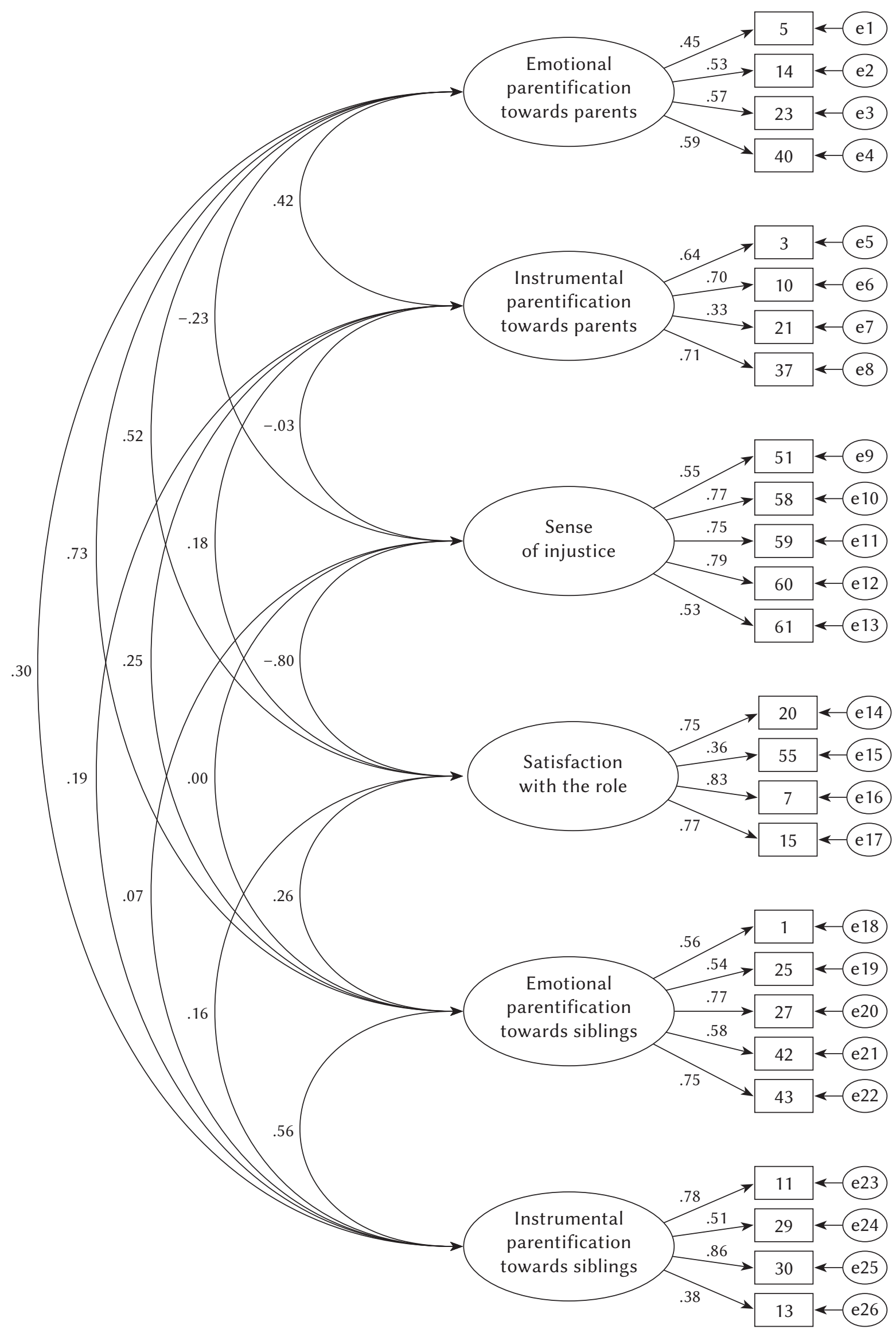

Parentification Questionnaire for Youth

Figure 4. Resultant path diagram of latent variables and test items for KPdM confirmatory factor analysis model for adolescents with siblings. 
Table 3

Standardized values of pathway coefficients $(\beta)$ in the model of KPdM confirmatory factor analysis (version for only children) for partial indices (test items) and latent variables (tool scales)

\begin{tabular}{|c|c|c|c|}
\hline $\begin{array}{c}\text { Test } \\
\text { position }\end{array}$ & & Latent variable & $\beta$ \\
\hline 5 & $\longleftarrow$ & \multirow{4}{*}{$\begin{array}{c}\text { Emotional } \\
\text { parentification } \\
\text { towards parents }\end{array}$} & .32 \\
\hline 14 & $\longleftarrow$ & & .42 \\
\hline 23 & $\longleftarrow$ & & .71 \\
\hline 40 & $\longleftarrow$ & & .53 \\
\hline 3 & $\longleftarrow$ & \multirow{4}{*}{$\begin{array}{l}\text { Instrumental } \\
\text { parentification } \\
\text { towards parents }\end{array}$} & .97 \\
\hline 10 & $\longleftarrow$ & & .61 \\
\hline 21 & $\longleftarrow$ & & .35 \\
\hline 37 & $\longleftarrow$ & & .63 \\
\hline 51 & $\longleftarrow$ & \multirow{5}{*}{$\begin{array}{l}\text { Sense of } \\
\text { injustice }\end{array}$} & .54 \\
\hline 58 & $\longleftarrow$ & & .52 \\
\hline 59 & $\longleftarrow$ & & .65 \\
\hline 60 & $\longleftarrow$ & & .73 \\
\hline 61 & $\longleftarrow$ & & .48 \\
\hline 20 & $\longleftarrow$ & \multirow{4}{*}{$\begin{array}{l}\text { Satisfaction } \\
\text { with the role }\end{array}$} & .72 \\
\hline 55 & $\longleftarrow$ & & .32 \\
\hline 7 & $\longleftarrow$ & & .91 \\
\hline 15 & $\longleftarrow$ & & .71 \\
\hline
\end{tabular}

\section{RELIABILITY}

In order to assess the reliability of the KPdM's scores, composite reliability (CR) coefficients were calculated, as recommended by Peterson and Kim (2013). Although the alpha coefficient (Cronbach, 1951) is the most widely used method for estimating the internal consistency, it is criticised as underestimating true reliability and being used without previously checking if its assumptions have been met (Osburn, 2000; Peterson \& Kim, 2013; Cho, 2016).

The evaluation of the composite reliability (CR) coefficients indicated that the measured variables in both tested models were characterized by an acceptable level of reliability $(\geq 0.7)$. The results are presented in Tables 5 and 6 .

\section{VALIDITY}

The test item distributions and the relations between the KPdM subscales were consistent with theoretical assumptions (see: Hornowska, 2001), which speaks for the test validity. Furthermore, test validity was
Table 4

Standardized values of pathway coefficients $(\beta)$ in the model of KPdM confirmatory factor analysis (version for adolescents with siblings) for partial indices (test items) and latent variables (tool scales)

\begin{tabular}{|c|c|c|c|}
\hline $\begin{array}{c}\text { Test } \\
\text { position }\end{array}$ & & Latent variable & $\beta$ \\
\hline 5 & $\longleftarrow$ & \multirow{4}{*}{$\begin{array}{c}\text { Emotional } \\
\text { parentification } \\
\text { towards parents }\end{array}$} & .45 \\
\hline 14 & $\longleftarrow$ & & .63 \\
\hline 23 & $\longleftarrow$ & & .57 \\
\hline 40 & $\longleftarrow$ & & .59 \\
\hline 3 & $\longleftarrow$ & \multirow{4}{*}{$\begin{array}{l}\text { Instrumental } \\
\text { parentification } \\
\text { towards parents }\end{array}$} & .64 \\
\hline 10 & $\longleftarrow$ & & .70 \\
\hline 21 & $\longleftarrow$ & & .33 \\
\hline 37 & $\longleftarrow$ & & .71 \\
\hline 51 & $\longleftarrow$ & \multirow{5}{*}{$\begin{array}{l}\text { Sense of } \\
\text { injustice }\end{array}$} & .55 \\
\hline 58 & $\longleftarrow$ & & .77 \\
\hline 59 & $\longleftarrow$ & & .79 \\
\hline 60 & $\longleftarrow$ & & .53 \\
\hline 61 & $\longleftarrow$ & & .48 \\
\hline 20 & $\longleftarrow$ & \multirow{4}{*}{$\begin{array}{l}\text { Satisfaction } \\
\text { with the role }\end{array}$} & .75 \\
\hline 55 & $\longleftarrow$ & & .36 \\
\hline 7 & $\longleftarrow$ & & .83 \\
\hline 15 & $\longleftarrow$ & & .77 \\
\hline 1 & $\longleftarrow$ & \multirow{5}{*}{$\begin{array}{c}\text { Emotional } \\
\text { parentification } \\
\text { towards siblings }\end{array}$} & .56 \\
\hline 25 & $\longleftarrow$ & & .54 \\
\hline 27 & $\longleftarrow$ & & .77 \\
\hline 42 & $\longleftarrow$ & & .58 \\
\hline 43 & $\longleftarrow$ & & .75 \\
\hline 11 & $\longleftarrow$ & \multirow{4}{*}{$\begin{array}{l}\text { Instrumental } \\
\text { parentification } \\
\text { towards siblings }\end{array}$} & .78 \\
\hline 29 & $\longleftarrow$ & & .51 \\
\hline 30 & $\longleftarrow$ & & .86 \\
\hline 13 & $\longleftarrow$ & & .38 \\
\hline
\end{tabular}

also assessed as suggested by Dimitrov (2012). Specifically, we examined whether KPdM scores correlated with chosen measures in theoretically expected ways. The following measures were used: subjective parental conflict assessment and subjective assessment of family socio-economic status (SES). Results of Pearson's $r$ correlations are presented in Table 7.

As parents in severe conflict are one of the highrisk factors for parentification in the family (Peris, Goeke-Morey, Cummings, \& Emery, 2008; Schier, 2014), we expected a positive correlation between 
sense of injustice and parental conflict, which was confirmed by the analysis $(r=.36, p<.01)$. Also, satisfaction with the family role was negatively related to parental conflict $(r=-.38, p<.01)$. The more conflicted the parents were, the less satisfied were the adolescents with the role that they perform in the family and more sense of injustice they had. These results are consistent with the predictions and show the KPdM validity. Family SES was not significantly correlated with emotional and instrumental parentification either towards parents or siblings, yet it was slightly positively related to sense of injustice $(r=.19$, $p<.05)$ and negatively with satisfaction with the family role $(r=-.15, p<.01)$. The results are consistent with the previous studies' results which showed that low as well as high family SES promotes parentification (Lackie, 1983; Burton, 2007; Hooper et al., 2011a). Last but not least, the subscales referring to emotional and instrumental parentification were moderately positively correlated (effect sizes from $r=.26, p<.01$ to $r=.44, p<.01$ ). Those results also support the validity of KPdM as they are consistent with the accumu-

Table 5

Reliability of KPdM subscales (version for only children)

\begin{tabular}{ll}
\hline Variable & $\begin{array}{l}\text { Number } \\
\text { of items }\end{array}$ \\
\hline
\end{tabular}

\begin{tabular}{lcc}
\hline $\begin{array}{l}\text { Emotional parentification } \\
\text { towards parents }\end{array}$ & 4 & 0.7 \\
$\begin{array}{l}\text { Instrumental parentification } \\
\text { towards parents }\end{array}$ & 4 & 0.7 \\
$\begin{array}{l}\text { Sense of injustice } \\
\text { Satisfaction with the role }\end{array}$ & 5 & 0.8 \\
\hline
\end{tabular}

lated literature showing that children may serve in a variety of roles within the family, with both types of parentification (i.e., emotional and instrumental) occurring simultaneously (cf. Jurkovic, 1997; Kerig, 2005), as well as provide care to all members of the family (Hooper, 2009; Hooper et al., 2011b).

\section{DISCUSSION}

The presented Parentification Questionnaire for Youth (KPdM) is available in two versions. The first one is intended for only children and consists of 17 items based on 4 factors: emotional parentification directed at parents, instrumental parentification directed at parents, sense of injustice and satisfaction

Table 6

Reliability of KPdM subscales (version for adolescents with siblings)

\begin{tabular}{|c|c|c|}
\hline Variable & $\begin{array}{l}\text { Number } \\
\text { of items }\end{array}$ & $\mathrm{CR}$ \\
\hline $\begin{array}{l}\text { Emotional parentification } \\
\text { towards parents }\end{array}$ & 4 & 0.7 \\
\hline $\begin{array}{l}\text { Instrumental parentification } \\
\text { towards parents }\end{array}$ & 4 & 0.7 \\
\hline Sense of injustice & 5 & 0.8 \\
\hline Satisfaction with the role & 4 & 0.8 \\
\hline $\begin{array}{l}\text { Emotional parentification } \\
\text { towards siblings }\end{array}$ & 5 & 0.8 \\
\hline $\begin{array}{l}\text { Instrumental parentification } \\
\text { towards siblings }\end{array}$ & 4 & 0.7 \\
\hline
\end{tabular}

Parentification Questionnaire for Youth

\section{Table 7}

Correlations between KPdM subscales, family SES and parental conflict

\begin{tabular}{|c|c|c|c|c|c|c|c|c|}
\hline Variable & 1 & 2 & 3 & 4 & 5 & 6 & 7 & 8 \\
\hline $\begin{array}{l}\text { 1. Instrumental parentification } \\
\text { towards parents }\end{array}$ & & & & & & & & \\
\hline $\begin{array}{l}\text { 2. Emotional parentification } \\
\text { towards parents }\end{array}$ & $.26^{* *}$ & & & & & & & \\
\hline 3. Sense of injustice & $-.19^{* *}$ & $.13^{*}$ & & & & & & \\
\hline 4. Satisfaction with the family role & $.41^{* *}$ & .08 & $-.57^{* *}$ & & & & & \\
\hline $\begin{array}{l}\text { 5. Instrumental parentification } \\
\text { towards siblings }\end{array}$ & $.44^{* *}$ & $.30 * *$ & .04 & $.30 * *$ & & & & \\
\hline $\begin{array}{l}\text { 6. Emotional parentification } \\
\text { towards siblings }\end{array}$ & $.29^{* *}$ & $.36^{* *}$ & .13 & $.24^{* *}$ & $.63^{* *}$ & & & \\
\hline 7. Family SES & -.12 & -.08 & $-.15^{*}$ & $.19^{* *}$ & .01 & .00 & & \\
\hline 8. Parental conflict & -.09 & -.02 & $.36^{* *}$ & $-.38^{* *}$ & .00 & -.06 & -.12 & \\
\hline
\end{tabular}


Judyta Borchet, Aleksandra LewandowskaWalter, Piotr Połomski, Aleksandra Peplińska with the role played in the family system. The version for individuals with siblings is expanded with 9 items based on two additional factors: emotional parentification towards siblings and instrumental parentification towards siblings.

A strength of the presented questionnaire is its high usability. Poland lacks research that would allow researchers to determine the severity of the problem of parentification in the population. Due to the unavailability of standardised questionnaire methods, Polish research in the area of parentification has been based, for example, on case studies, qualitative methods, experimental versions of questionnaires or interviews (e.g. Schier, 2010; Błażek, 2016; Chojnacka, 2018; Jarzębińska \& Chojnacka, 2018).

This questionnaire contributes to the development of diagnostic methods in Poland. KPdM will facilitate a broader diagnosis of the phenomenon of parentification in Poland. It is a short, easy-to-use scale that can be a useful tool for psychologists and psychotherapists working with young people, especially those growing up in families experiencing stress due to divorce, economic migration of parents, disease of parents, limited parental competence and foster care placements. It will help assess the intensity of children's emotional burden associated with the reversal of roles and responsibilities they feel towards parents and siblings. Currently, researchers also draw attention to the need to study the phenomenon of parentification outside the United States and to look at it from a global perspective (Hooper, 2014). The scientific value of the Parentification Questionnaire for Youth will allow researchers to conduct intercultural research 1) in the scope of defining common mechanisms, independent of the environment in which children are brought up, reflecting the dependence of the welfare of children and youth on the situation in the family related to the reversal of roles, and 2) allowing researchers to highlight the specific character of the parentification process in Polish society, so that it will be possible to design preventive and therapeutic programmes.

\section{CONCLUSIONS}

The presented questionnaire is a reliable and valid tool allowing one to measure the intensity of parentification experienced by young people aged 12 to 18 . The questionnaire draws attention to the multidimensional character of the phenomenon of parentification, focusing on the type of roles and tasks performed by a teenager (i.e. emotional and instrumental parentification), the level of a sense of injustice and satisfaction with the role played in the family system. Additionally, the test allows us to focus on the recipient of the care provided by the child (parents or siblings) while maintaining a structure that allows research to be conducted with both only children and persons with siblings and facilitates comparison between them.

The questionnaire can be of use for research purposes and for diagnosing the situation of families, children's relations with parents and siblings. The team's further work will focus on the development of standards for the questionnaire.

\section{ACKNOWLEDGMENTS}

This work was supported by a Grant for young scientists and participants of doctoral studies at the University of Gdansk Faculty of Social Sciences for 2018 (538-7400-B185-18).

\section{References}

Bedyńska, S., \& Książek, M. (2012). Statystyczny Drogowskaz 3. Praktyczny przewodnik wykorzystania modeli regresji oraz równań strukturalnych [Statistical Guidebook 3. A practical guide to using regression models and structural equations]. Warszawa: Wydawnictwo Akademickie Sedno.

Błażek, M. (2016). Parental attitudes and parentification of children in families with limited parental care competencies. Polish Journal of Applied Psychology, 14, 93-108. https://doi.org/10.1515/pjap2015-0064

Boszormenyi-Nagy, I., \& Spark, G. M. (1973). Invisible loyalties: Reciprocity in intergenerational family therapy. Oxford, UK: Harper \& Row.

Burton, L. (2007). Childhood adultification in economically disadvantaged families: A conceptual model. Family Relations, 56, 329-345. https://doi. org/10.1111/j.1741-3729.2007.00463.x

Bowen, M. (1978) Family therapy in clinical practice. Lanham, MD: Rowman \& Littlefield.

Byng-Hall, J. (2008). The significance of children fulfilling parental roles: Implications for family therapy. Journal of Family Therapy, 30, 147-162. https://doi.org/10.1111/j.1467-6427.2008.00423.x

Chase, N., Deming, M., \& Wells, M. (1998). Parentification, parental alcoholism, and academic status among young adults. American Journal of Family Therapy, 26, 105-114. https://doi.org/10.1080/ 01926189808251091

Cho, E. (2016). Making reliability reliable. Organizational Research Methods, 19, 651-682. https://doi. org/10.1177/1094428116656239

Chojnacka, B. (2018). Doświadczenie parentyfikacji w rodzinie jako wyzwanie dla pracy socjalnej [The experience of parentification in the family as a challenge for social work]. Zeszyty Pracy Socjalnej, 23, 213-226. https://doi.org/10.4467/24496138Z PS.18.014.10069 
Cicchetti, D. (2004). An odyssey of discovery: Lessons learned through three decades of research on child maltreatment. American Psychologist, 59, 731-741. https://doi.org/10.1037/0003-066X.59.8.731

Cronbach, L. J. (1951). Coefficient alpha and the internal structure of tests. Psychometrika, 16, 297-334. https://doi.org/10.1007/BF02310555

Cudak, H. (2011). Dysfunkcje rodziny i jej zagrożenia opiekuńczo-wychowawcze [Family dysfunctions and care and educational threats]. Pedagogika Rodziny, 1, 7-14.

Dimitrov, D. M. (2012). Statistical methods for validation of assessment scale data in counseling and related fields. Alexandria, VA: American Counseling Association.

East, P. L. (2010). Children provision of family caregiving: Benefit or burden? Child Development Perspectives, 4, 55-61. https://doi.org/10.1111/j.17508606.2009.00118.x

Goodman, E., Adler, N. E., Kawachi, I., Frazier, A. L., Huang, B., \& Colditz, G. A. (2001). Adolescents' perceptions of social status: Development and evaluation of a new indicator. Pediatrics, 108, 31-39. https://doi.org/10.1542/peds.108.2.e31

Grzegorzewska, I. (2016). Parentyfikacja w rodzinach $\mathrm{z}$ problemem alkoholowym [Parentification in families with alcohol-related problems]. Alcoholism and Drug Addiction, 29, 27-38. https://doi.org 10.1016/j.alkona.2016.03.004

Hofstede, G. (2011). Dimensionalizing cultures: The Hofstede model in context. Online Readings in Psychology and Culture, 2, 8. https://doi.org/10. 9707/2307-0919.1014

Hooper, L. M. (2007). The application of attachment theory and family systems theory to the phenomena of parentification. The Family Journal, 15, $217-$ 223. https://doi.org/10.1177/1066480707301290

Hooper, L. M. (2009). Parentification Inventory. Available from L. M. Hooper, 108 Schindler Education Center, University of Northern Iowa, Cedar Falls, lowa, 50614-0410.

Hooper, L. M. (2012). Parentification. In R. J. R. Levesque (Ed.), Encyclopedia of adolescence (pp. 20232031). New York, NY: Springer.

Hooper, L. M. (2014). Assessing parentification in South American college students: A factor analytic study of a Spanish version of the Parentification Inventory. Journal of Multicultural Counseling and Development, 42, 93-106. https://doi. org/10.1002/j.2161-1912.2014.00047.x

Hooper, L. M., DeCoster, J., White, N., \& Voltz, M. L. (2011a). Characterizing the magnitude of the relation between self-reported childhood parentification and adult psychopathology: A meta-analysis. Journal of Clinical Psychology, 67, 1028-1043. https://doi.org/10.1002/jclp.20807

Hooper, L. M., Doehler, K., Wallace, S. A., \& Hannah, N. J. (2011b). The Parentification Inventory: De- velopment, validation and cross-validation. American Journal of Family Therapy, 39, 226-241. https:// doi.org/10.1080/01926187.2010.531652

Hooper, L. M., Marotta, S. A., \& Lanthier, R. P. (2008). Predictors of growth and distress following childhood parentification: A retrospective exploratory study. Journal of Child \& Family Studies, 17, 693705. https://doi.org/10.1007/s10826-007-9184-8

Hooper, L. M., \& Wallace, S. A. (2010). Evaluating the Parentification Questionnaire: Psychometric properties and psychopathology correlates. Contemporary Family Therapy, 32, 52-68. https://doi. org/10.1007/s10591-009-9103-9

Hornowska, E. (2001). Testy psychologiczne. Teoria i praktyka [Psychological tests. Theory and practice]. Warszawa: Wydawnictwo Scholar.

Jarzębińska, A., \& Chojnacka, B. (2018). „Karmienie się dzieckiem na żądanie" - doświadczenie parentyfikacji w relacjach uczestników internetowych forów dyskusyjnych [,Feeding on your child on demand" - the experience of parentification in the stories presented by the participants of online discussion forums]. Dziecko Krzywdzone. Teoria, badania, praktyka, 17, 165-185.

Jones, R., \& Wells, M. (1996). An empirical study of parentification and personality. American Journal of Family Therapy, 24, 145-152. https://doi. org/10.1080/01926189608251027

Jurkovic, G. J. (1997). Lost childhoods: The plight of the parentified child. New York, NY: Brunner/Mazel, Inc.

Jurkovic, G. J., Kuperminc, G. P., Sarac, T., \& Weisshaar, D. (2005). Role of filial responsibility in the post-war adjustment of Bosnian young adolescents. Journal of Emotional Abuse, 5, 219-235. https://doi.org/10.1300/ J135v05n04_03

Jurkovic, G. J., \& Thirkield, A. (1998). Parentification questionnaire. Available from G. J. Jurkovic, Department of Psychology, Georgia State University, University Plaza, Atlanta, GA 30303.

Jurkovic, G. J., \& Thirkield, A. (1999). Filial Responsibility Scale-Adult (FRS-A). Available from Gregory J. Jurkovic, Department of Psychology, Georgia State University, University Plaza, Atlanta, GA 30303.

Jurkovic, G. J., Thirkield, A., \& Morrell, R. (2001). Parentification of adult children of divorce: A multidimensional analysis. Journal of Youth and Adolescence, 30, 245-257. https://doi.org/10.1023/A: 1010349925974

Kerig, P. K. (2005). Revisiting the construct of boundary dissolution: A multidimensional perspective. Journal of Emotional Abuse, 5, 5-42. https://doi. org/10.1300/J135v05n02_02.

Kerig, P. K., \& Brown, C. A. (1996). The Parent-Child Boundaries Scale. Unpublished manuscript. Department of Psychology, Simon Fraser University. Kolankiewicz, M. (2017). Dzieci poza rodziną [Children in alternative care]. Dziecko Krzywdzone. Teoria, badania, praktyka, 16, 68-93.
Parentification Questionnaire for Youth 
Konarski, R. (2010). Modele równań strukturalnych. Teoria i praktyka [Structural equation modeling. Theory and practice]. Warszawa: Wydawnictwo Naukowe PWN.

Lackie, B. (1983). The families of origin of social workers. Clinical Social Work Journal, 11, 309-322. https://doi.org/10.1007/BF00755898

Macfie, J., Brumariu, L. E., \& Lyons-Ruth, K. (2015). Parent-child role-confusion: A critical review of an emerging concept. Developmental Review, 36, 34-57. https://doi.org/10.1016/j.dr.2015.01.002

Judyta Borchet, Aleksandra LewandowskaWalter, Piotr Połomski, Aleksandra Peplińska

McMahon, T. J., \& Luthar, S. S. (2007). Defining characteristics and potential consequences of caretaking burden among children living in urban poverty. American Journal of Orthopsychiatry, 77, 267-281. https://doi.org/10.1037/0002-9432.77.2.267
Minuchin, S., Montalvo, B., Guerney, B., Rosman, B., \& Schumer, F. (1967). Families of the slums. New York: Basic Books.

Nuttall, A. K., \& Valentino, K. (2017). An ecologicaltransactional model of generational boundary dissolution across development. Marriage \& Family Review, 53, 105-150. https://doi.org/10.1080/01494 929.2016.1178203

Nuttall, A. K., Zhang, Q., Valentino, K., \& Borkowski, J. G. (2019). Intergenerational risk of parentification and infantilization to externalizing moderated by child temperament. Journal of Marriage and Family, 81, 648-661. https://doi.org/10.1111/jomf. 12562

Osburn, H. G. (2000). Coefficient alpha and related internal consistency reliability coefficients. Psychological Methods, 5, 343-355. https://doi.org/ 10.1037/1082-989x.5.3.343

Peris, T. S., Goeke-Morey, M. C., Cummings, E. M., \& Emery, R. E. (2008). Marital conflict and support seeking by parents in adolescence: Empirical support for the parentification construct. Journal of Family Psychology, 22, 633-642. https://doi. org/10.1037/a0012792

Peterson, R. A., \& Kim, Y. (2013). On the relationship between coefficient alpha and composite reliability. Journal of Applied Psychology, 98, 194-198. https://doi.org/10.1037/a0030767

Richardson, R. W., \& Richardson, L. A. (1999). Najstarsze, średnie, najmtodsze. Jak kolejność narodzin wptywa na twój charakter [Oldest, medium, youngest. How the order of birth affects your character] Gdańsk: Gdańskie Wydawnictwo Psychologiczne.

Roberts, L. C., \& Blanton, P. W. (2001)."I always knew that mom and dad loved me best": Experiences of only children. Journal of Individual Psychology, 57, 125-140.

Schier, K. (2010). Gdy dziecko staje się rodzicem odwrócona troska, czyli zjawisko parentyfikacji w rodzinie [When a child becomes a parent - reversed care, the phenomenon of parentification in the family]. In B. Tryjarska (Ed.), Bliskość w rodzinie. Więzi w dzieciństwie a zaburzenia $w$ doro- stości [Closeness in the family. Ties in childhood and disorders in adulthood] (pp. 63-80). Warszawa: Wydawnictwo Naukowe Scholar.

Schier, K. (2014). Doroste dzieci. Psychologiczna problematyka odwrócenia ról w rodzinie [Adult children. Psychological issues of reversing roles in the family]. Warszawa: Wydawnictwo Naukowe Scholar.

Schier, K. (2019). Formy pomocy niewidzialnym dzieciom, czyli tym, które doświadczyły odwrócenia ról w rodzinie [The forms of help to invisible children - children who had experienced role reversal in the family]. Dziecko Krzywdzone. Teoria, badania, praktyka, 17, 28-50.

Sikorska, M. (2009). Nowa matka, nowy ojciec, nowe dziecko. O nowym układzie sit w polskich rodzinach [New mother, new father, new child. On the new balance of power in Polish families]. Warszawa: Wydawnictwa Akademickie i Profesjonalne.

Shaffer, A., \& Madden, A. R. (2016). The relation between parentification and dating communication: the role of romantic attachment-related cognitions. The Family Journal, 24, 313-318. https://doi. org/10.1177/1066480716648682

Slany, K. (2002). Alternatywne formy życia matżeńsko-rodzinnego w ponowoczesnym świecie [Alternative forms of married and family life in the postmodern world]. Kraków: ZW Nomos.

Sorensen, B. (2008). Only child experience and adulthood. New York: Palgrave Macmillan

Sroufe, L. A., \& Ward, M. J. (1980). Seductive behavior of mothers of toddlers: Occurrence, correlates, and family origins. Child Development, 51, 12221229. https://doi.org/10.2307/1129564

Szredzińska, R. (2017). Zdrowie dzieci i młodzieży [Health of children and youth]. Dziecko Krzywdzone. Teoria, badania, praktyka, 16, 94-131.

Szymańczak, J. (2016). Children "taken" from their parents: the reasons for putting children in foster care in Poland. Analizy Biura Analiz Sejmowych, 5, 1-7.

Tarka, K. (2014). Sytuacja dziecka w rodzinie migracyjnej [The situation of the child in a migrant family]. Studia i Prace Pedagogiczne, 1, 169-180.

Tedgård, E., Råstam, M., \& Wirtberg, I. (2019). An upbringing with substance-abusing parents: Experiences of parentification and dysfunctional communication. Nordic Studies on Alcohol and Drugs, 36, 223-247. https://doi.org/10.1177/1455072518814308

Żarczyńska-Hyla, J., Zdaniuk, B., Piechnik-Borusowska, J., Karcz-Taranowicz, E., \& Kromolicka, B. (2016). Uwarunkowania parentyfikacji doświadczanej w dzieciństwie i okresie dorastania z perspektywy młodych dorosłych [Parentification correlates experienced in childhood and adolescence from the perspective of young adults]. Rocznik Andragogiczny, 23, 199-215. https://doi.org/10.12775/ RA.2016.010 